ENTREPRENEURSHIP AND SUSTAINABILITY ISSUES

ISSN 2345-0282 (online) http://jssidoi.org/jesi/ 2021 Volume 9 Number 1 (September)

http://doi.org/10.9770/jesi.2021.9.1(25)
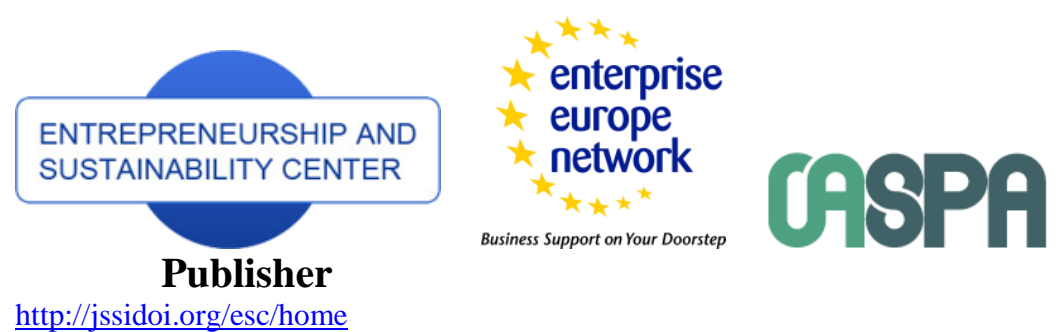

Business Support on Your Doorstep

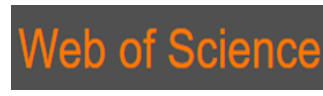

http://jssidoi.org/esc/home

1 Clarivate

Analytics

\title{
MAPPING THE STRATEGIC LANDSCAPE FOR GLOBAL FINANCIAL INSTITUTIONS THROUGH BRAND EQUITY TREND ANALYSIS
}

\author{
Ishtiaq Bajwa ${ }^{1}$, Kamran Siddiqui ${ }^{2}$, Tarig Eltayeb ${ }^{3}$, Chaudhry K. Mahmood ${ }^{4}$ \\ 1,2,3,4 Imam Abdulrahman Bin Faisal University, Dammam, Saudi Arabia

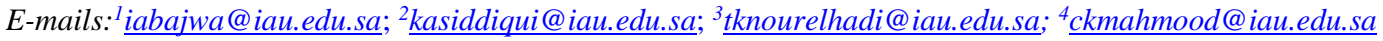

Received 15 May 2021; accepted 13 July 2021; published 30 September 2021

\begin{abstract}
This paper aims to present the strategic landscape for global financial institutions through a trend analysis for Interbrand's top 100 global brands. The study used longitudinal data of 20 years (2001 to 2020) from the top 100 global brands published by Interbrand annually. Analyses are based on Interbrand's brand equity (\$ millions), annual brand ranking, and annual growth in brand equity using descriptive statistics. This research provides three significant findings. Firstly, it supports the country of origin's effect on top Financial Institutions. American financial institutions were always ahead of financial institutions from other countries. European banks have a relatively higher growth rate. Secondly, this research proposes three clusters of global financial institutions. Leaders include financial institutions that appeared in Interbrand's Global brand list for at least 15 years during 2001-2020 and having minimum brand equity of USD 8.0 billion in 2020. Challengers include financial institutions that appeared in Interbrand's global brand list for at least five years during 2001-2020; and having minimum brand equity of USD 7.0 billion in 2020. Extinct include financial institutions that appeared in Interbrand's global brand list at least once during 2001-2020 but not listed for the last eight years. Finally, this paper presents the effects of the global financial crisis (2008) and global pandemic (2020) on financial institutions. The global financial crisis (2008-9) deeply affected the global banking industry. Many banks were forced to close, and governments had to bail them out. The financial stocks were crushed, and many of them were slashed. The collapse of the US financial system caused many investors to lose their money. The brand equity of financial institutions has the most significant decline. While the global pandemic crisis (2019-20) completely halted the world's economy for many months, the bank's brand equity was not severely affected. Although in 2019-20, there was a decline in the growth rate of the financial sector's brand equity compared to all other sectors, the cumulative brand equity of the financial sector was constantly on the rise. These findings have implications for practitioners and academicians to understand better the underlying patterns and changes in top global financial institutions' brand equity and devise the appropriate strategies. In addition, the findings invite future research on probing the reasons behind the drastic changes in the brand equity of various global financial institutions in the last two decades.
\end{abstract}

Keywords: Trend Analysis; Brand Equity; Financial institutions

Reference to this paper should be made as follows: Bajwa, I., Siddiqui, K.., Eltayeb, T., Mahmood, C.K. 2021. Mapping the strategic landscape for global financial institutions through brand equity trend analysis. Entrepreneurship and Sustainability Issues, 9(1), $401-414$. http://doi.org/10.9770/jesi.2021.9.1(25)

JEL Classifications: L26 


\section{ENTREPRENEURSHIP AND SUSTAINABILITY ISSUES}

ISSN 2345-0282 (online) http://jssidoi.org/jesi/

2021 Volume 9 Number 1 (September)

http://doi.org/10.9770/jesi.2021.9.1(25)

\section{Introduction}

Strategy is core to any bank's growth, and often their success is due to strategic rather than operational reasons. One of the primary reasons for their success is the familiarity of their senior management with the strategic landscape in which their bank operates. In other words, those banks having a better knowledge of their strategic landscapes are likely to get a competitive advantage over their competitors. One of the critical ingredients of successful competitive strategies is following the strategic maps, which display the location of their own and rival banks. A bank's strategic landscape is typically analyzed in terms of the bank's competitive position, the banking industry conditions under which the banks operate, and the core strategies banks in the industry are following. The purpose of this paper is to present the strategic landscape for global financial institutions through a trend analysis for Interbrand's top 100 global brands.

\section{Literature Review}

Interbrand, the world's leader in brand management consulting business, publishes an annual ranking of the world's best 100 global brands for the last two decades (Interbrand, 2020). Interbrand's ranking receives equal acceptance and appreciation by the industry and academia (Jia, \& Zhang, 2013) as it is relatively easy to understand and apply in practice (Vasileva, 2016). This research aims to present the trend analysis for Interbrand's top financial institutions (2001-2020), and it provides distinction on many counts. Firstly, literature is abundant on brand equity or its valuation methods, but brand equity research is not common (Siddiqui, 2011; Rifi, \& Mostafa, 2021; Manu et al., 2021; Rambocas, \& Arjoon, 2020).

Secondly, there is a plethora of literature exists on financial institutions from various perspectives. Still, financial institutions were never studied earlier for their brand equity trends. Finally, studies linking global crises to global financial institutions are limited but empirically proved that the bank's profitability suffers during the crisis (Teixeira, Silva, Costa, Martins, \& Batista, 2020) either global financial crisis or Asian financial crisis. Similarly, literature linking the global financial crisis to brand equity trends is very thin (Siddiqui, Bajwa, \& Elahi, 2018); mainly, financial institutions were never studied for their links with the global crisis.

Brand equity refers to "the differential effect that brand knowledge has on consumer response to the brand's marketing," having three dimensions: differential effect, brand knowledge, and consumer response (Keller, 1993). It creates value for target markets that leads to profitability and profit growth. Since its inception, there have been numerous efforts to measure brand equity, including the most prominent ones such as Simon and Sullivan's brand equity valuation (Simon, \& Sullivan, 1993) and Interbrand's brand valuation methodology (Chu, \& Keh, 2006). Interbrand's brand valuation approach is considered the most trusted and renowned method of measuring brand equity (Harjoto, \& Salas, 2017). Interbrand estimates the brand equity by turning the future income into present value based on the financial market value technique (Chu, \& Keh, 2006). In addition, Interbrand ensures multiple criteria while developing the Top 100 global brands ranking (Interbrand's criteria, 2021). Based on this evaluation method, Interbrand publishes 100 Best Global Brands list every year since 2001, and these criteria include (Table $1)$ : 


\section{ENTREPRENEURSHIP AND SUSTAINABILITY ISSUES}

ISSN 2345-0282 (online) http://jssidoi.org/jesi/ 2021 Volume 9 Number 1 (September) http://doi.org/10.9770/jesi.2021.9.1(25)

Table 1. Interbrand's Criteria for Selecting Brands in the Top 100 Brands (2001-2020)

\begin{tabular}{|c|c|}
\hline No. & Criteria for Selecting Brands in the Top 100 Brands (2001-2020) \\
\hline 1. & The brand should be global, with at least one-third of earnings coming from outside the home country. \\
\hline 2. & The economic profit is expected to be positive over the longer term, delivering a return above the brand's cost of capital. \\
\hline 3. & The brand should be market-facing and should not have a purely monopolistic condition with broader awareness. \\
\hline 4. & The brand's parent firm must be publicly listed with publicly available financial data. \\
\hline 5. & The brand must have a significant presence in Asia, Europe, and North America and geographic coverage in emerging markets. \\
\hline 6. & The brand must have a public profile and sufficient awareness across the major economies of the world. \\
\hline 7. & The Economic Value Added (EVA) must be positive, and the brand value must be over USD 1 billion (USD 4 billion in 2021). \\
\hline
\end{tabular}

Source: Interbrand

Interbrand methodology has increasingly being used for assessing a bank's brand value (Melović, Vukčević, \& Dabić, 2021). They have illustrated how the brand value of a bank is calculated using the Interbrand methodology. Empirically they have presented the role of brands in enhancing the profitability of banks. The study shows that the profitability of a bank brand is the most significant factor that influences the value of a bank brand. The paper overcomes the gap between theory and practice by focusing on the various aspects of banking. This is because implementing the Interbrand methodology in this field of study is still in its early stages. The findings of this study have positive implications for banks' external and internal stakeholders. The methodology used in this research has been optimized in order to measure the brand of banks.

Literature suggests that global banks are more vulnerable to global crises (Cetorelli, \& Goldberg, 2011). A plethora of literature suggests that the global economic recession (2008-2009) affected the banks worldwide. The crisis led to a significant decline in banking (Cull, \& Peria, 2013). This global crisis affected those countries which more integrated into the global economy, and therefore more vulnerable to the impact of the global economic crisis (Bartlett, \& Prica, 2011; Coleman, \& Feler, 2015)—also supported by the minor damage of financial crisis to the Middle Eastern banks having minor global integration with overseas asset financing (Habibi, 2009). This trend has also been observed for global financial institutions' brand equity trend analysis during the global financial crisis. The growth rate of brand equity for financial institutions went as low as $-21 \%$ during the 2008 crises period (Siddiqui, Bajwa, \& Elahi, 2018). Similarly, an abundance of literature suggesting the global pandemic crisis (2019-20) also affected banking systems worldwide (Demirgüç-Kunt, Pedraza, \& Ruiz Ortega, 2020). Banks have taken measures to retract from supervisory COVID-19 support measures without perils for financial stability (Haselmann, \& Tröger, 2021). Now, recovery signals for bank stability during the second quarter of 2020 (Elnahass, Trinh, \& Li, 2021). However, the literature is almost absent on the impact of the COVID-19 crisis on brand equity.

\section{Research Objective and Methodology}

This paper proposes mapping the strategic landscape for global financial institutions through trend analysis of brand equity using Interbrand's Top 100 Global Brand (2001-2020). These maps enable banks to assess their strategic locations and performances longitudinally. Finally, different clusters were formed based on their brand equity performance. This study used longitudinal data from Interbrand's top 100 global brands list for 20 years (2001 to 2020). Interbrand estimates the brand equity by turning the future income into present value based on the financial market value technique. Thus, it makes the basis for the ranking of brands. During the last 20 years (2001 -2010), 19 financial institutions from seven countries appeared in the top 100 global brands (Table 2). 
Table 2. Financial institutions Appeared Among the Top 100 Brands (2001-2020)

\begin{tabular}{|c|c|c|c|c|}
\hline No. & Brand & Country & Region & Appearances* \\
\hline 1 & Goldman Sachs & US & America & 20 \\
\hline 2 & Citi & US & America & 20 \\
\hline 3 & American Express & US & America & 20 \\
\hline 4 & JPMorgan & US & America & 19 \\
\hline 5 & Morgan Stanley & US & America & 19 \\
\hline 6 & HSBC & UK & Europe & 18 \\
\hline 7 & Allianz & Germany & Europe & 14 \\
\hline 8 & AXA & France & Europe & 14 \\
\hline 9 & Visa & US & America & 13 \\
\hline 10 & Santander & Spain & Europe & 11 \\
\hline 11 & MasterCard & US & America & 9 \\
\hline 12 & PayPal & US & America & 6 \\
\hline 13 & Merrill & US & America & 8 \\
\hline 14 & UBS & Switzerland & Europe & 8 \\
\hline 15 & ING & Netherland & Europe & 5 \\
\hline 16 & Credit Suisse & Switzerland & Europe & 3 \\
\hline 17 & AIG & US & America & 2 \\
\hline 18 & Barclays & UK & Europe & 2 \\
\hline 19 & Zurich & Switzerland & Europe & 2 \\
\hline
\end{tabular}

* Number of appearances in Interbrand's list of Top 100 Global Brands (2001-2020) Source: Interbrand

\section{Results and Discussion}

Analyses are based on Interbrand's brand equity (\$ millions), annual brand ranking, and annual growth in brand equity using descriptive statistics. This research provides three significant findings: (a) country of origin effect on top financial institutions; (b) brand equity trends among financial institutions; (c) financial institutions cluster formation; and (d) effects of the global financial crisis (2008) and global pandemic (2020) on the financial institutions.

\subsection{Country of origin}

Regarding Interbrand's 100 best global brands for the last 20 years, the country of origin for financial institutions is restricted to only seven countries (Table 3). These countries include France, Germany, Netherland, Spain, Switzerland, UK, and the USA. Therefore, these brands can be grouped on their subcontinents (Table 4), and American brands dominate the global financial industry. These findings also support the earlier research showing the impact of country of origin (COO) on Interbrand's top 100 global brands (Siddiqui, \& Sibghatullah, 2014).

Table 3. Number of Financial institutions among Top 100 Brands - Country wise Summary

\begin{tabular}{|c|c|c|c|c|c|c|c|c|c|c|c|c|c|c|c|c|c|c|c|c|}
\hline Country & $\stackrel{\widetilde{\sigma}}{\sigma}$ & ్ㅗㅇ & 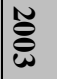 & $\stackrel{N}{\varnothing}$ & ֻै & $\stackrel{\text { ̊̆ }}{8}$ & 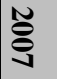 & 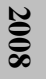 & 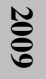 & 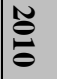 & $\stackrel{N}{\Theta}$ & $\stackrel{N}{\stackrel{N}{N}}$ & $\stackrel{N}{\stackrel{\tilde{\omega}}{\omega}}$ & 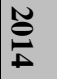 & 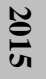 & $\stackrel{\widetilde{N}}{\stackrel{\tilde{\sigma}}{\sigma}}$ & $\stackrel{N}{\Theta}$ & 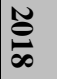 & $\stackrel{\frac{N}{\varrho}}{b}$ & N \\
\hline France & 0 & 0 & 0 & 0 & 0 & 0 & 1 & 1 & 1 & 1 & 1 & 1 & 1 & 1 & 1 & 1 & 1 & 1 & 1 & 1 \\
\hline Germany & 0 & 0 & 0 & 0 & 0 & 0 & 1 & 1 & 1 & 1 & 1 & 1 & 1 & 1 & 1 & 1 & 1 & 1 & 1 & 1 \\
\hline Netherland & 0 & 0 & 0 & 1 & 1 & 1 & 1 & 1 & 0 & 0 & 0 & 0 & 0 & 0 & 0 & 0 & 0 & 0 & 0 & 0 \\
\hline Spain & 0 & 0 & 0 & 0 & 0 & 0 & 0 & 0 & 0 & 1 & 1 & 1 & 1 & 1 & 1 & 1 & 1 & 1 & 1 & 1 \\
\hline Switzerland & 0 & 0 & 0 & 1 & 1 & 1 & 1 & 1 & 1 & 3 & 3 & 1 & 0 & 0 & 0 & 0 & 0 & 0 & 0 & 0 \\
\hline UK & 0 & 0 & 1 & 1 & 1 & 1 & 1 & 1 & 1 & 2 & 2 & 1 & 1 & 1 & 1 & 1 & 1 & 1 & 1 & 1 \\
\hline USA & 4 & 6 & 6 & 6 & 6 & 6 & 7 & 8 & 6 & 6 & 6 & 7 & 7 & 7 & 8 & 8 & 8 & 8 & 8 & 8 \\
\hline
\end{tabular}


Table 4. Number of Financial institutions among Top 100 Brands - Region wise Summary

\begin{tabular}{|c|c|c|c|c|c|c|c|c|c|c|c|c|c|c|c|c|c|c|c|c|}
\hline Region & $\stackrel{ }{8}$ & 용 & $\stackrel{\sim}{\mathbf{\sigma}}$ & $\stackrel{ }{8}$ & 용 & 용 & 용 & 요 & $\stackrel{8}{8}$ & $\stackrel{N}{\theta}$ & $\stackrel{N}{\varrho}$ & $\stackrel{N}{\Theta}$ & $\stackrel{N}{e}$ & $\stackrel{N}{\ominus}$ & 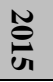 & $\stackrel{N}{\stackrel{0}{\sigma}}$ & $\underset{\vartheta}{\ominus}$ & $\underset{\infty}{\infty}$ & $\underset{0}{0}$ & 옹 \\
\hline USA & 4 & 6 & 6 & 6 & 6 & 6 & 7 & 8 & 6 & 6 & 6 & 7 & 7 & 7 & 8 & 8 & 8 & 8 & 8 & 8 \\
\hline Europe & 0 & 0 & 1 & 3 & 3 & 3 & 5 & 5 & 4 & 8 & 8 & 5 & 4 & 4 & 4 & 4 & 4 & 4 & 4 & 4 \\
\hline
\end{tabular}

\subsection{Brand equity trends}

Figure 1 presents a cumulative brand equity trend of all banks on Interbrand's Top 100 Global Brands list (20012020). In 2001, the cumulative brand equity of all banks was $\$ 59$ billion, and it has increased many folds to reach $\$ 149$ billion in 2020 .

Figure 2 shows a region-wise summary of cumulative brand equity. Again, American financial institutions have performed outstandingly on the brand equity front. At the same time, European banks have also made their brand name on a global level.

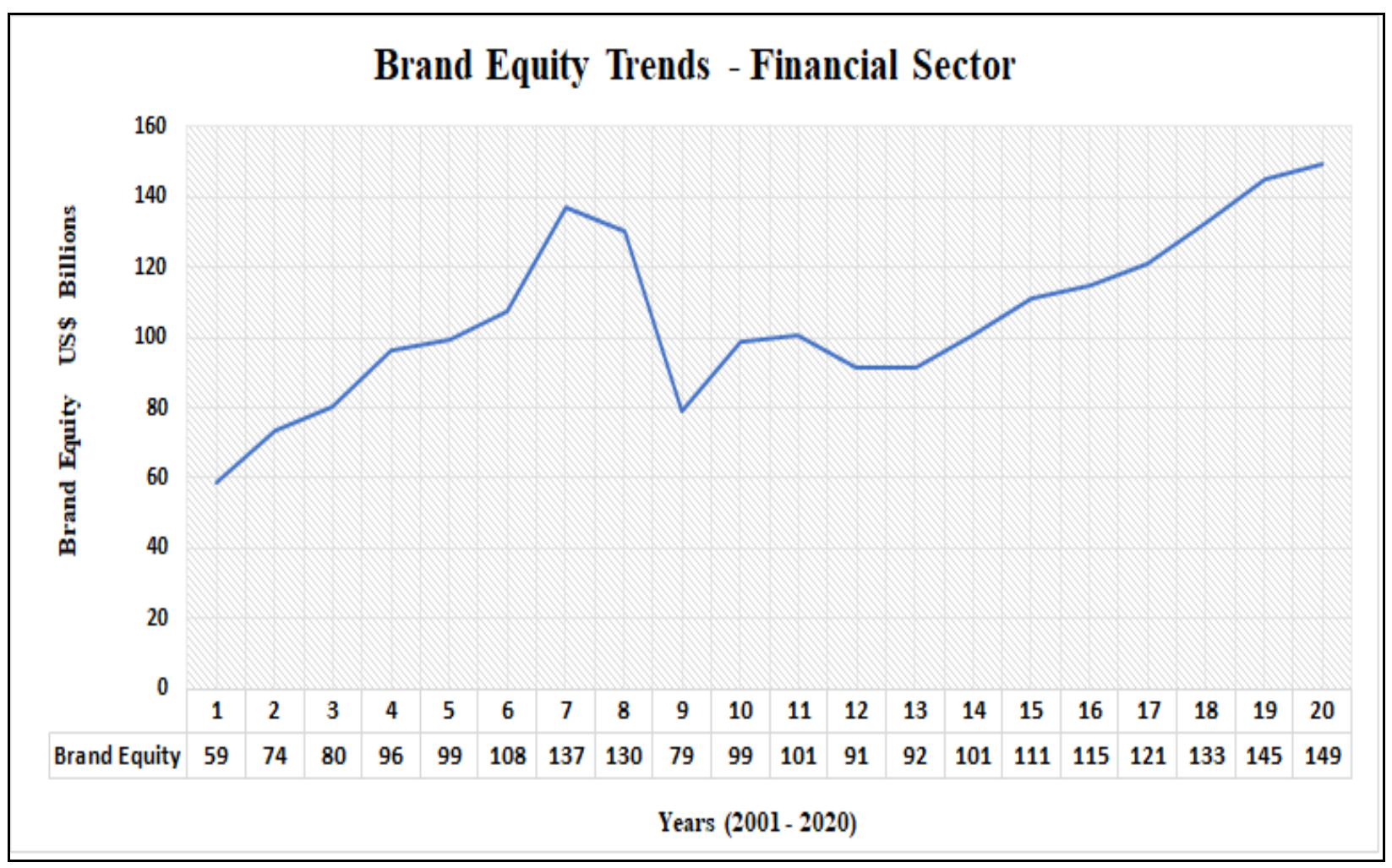

Fig. 1. Brand Equity Trends for Financial institutions (2001-2020) - Cumulative Summary

Source: Authors' contribution 


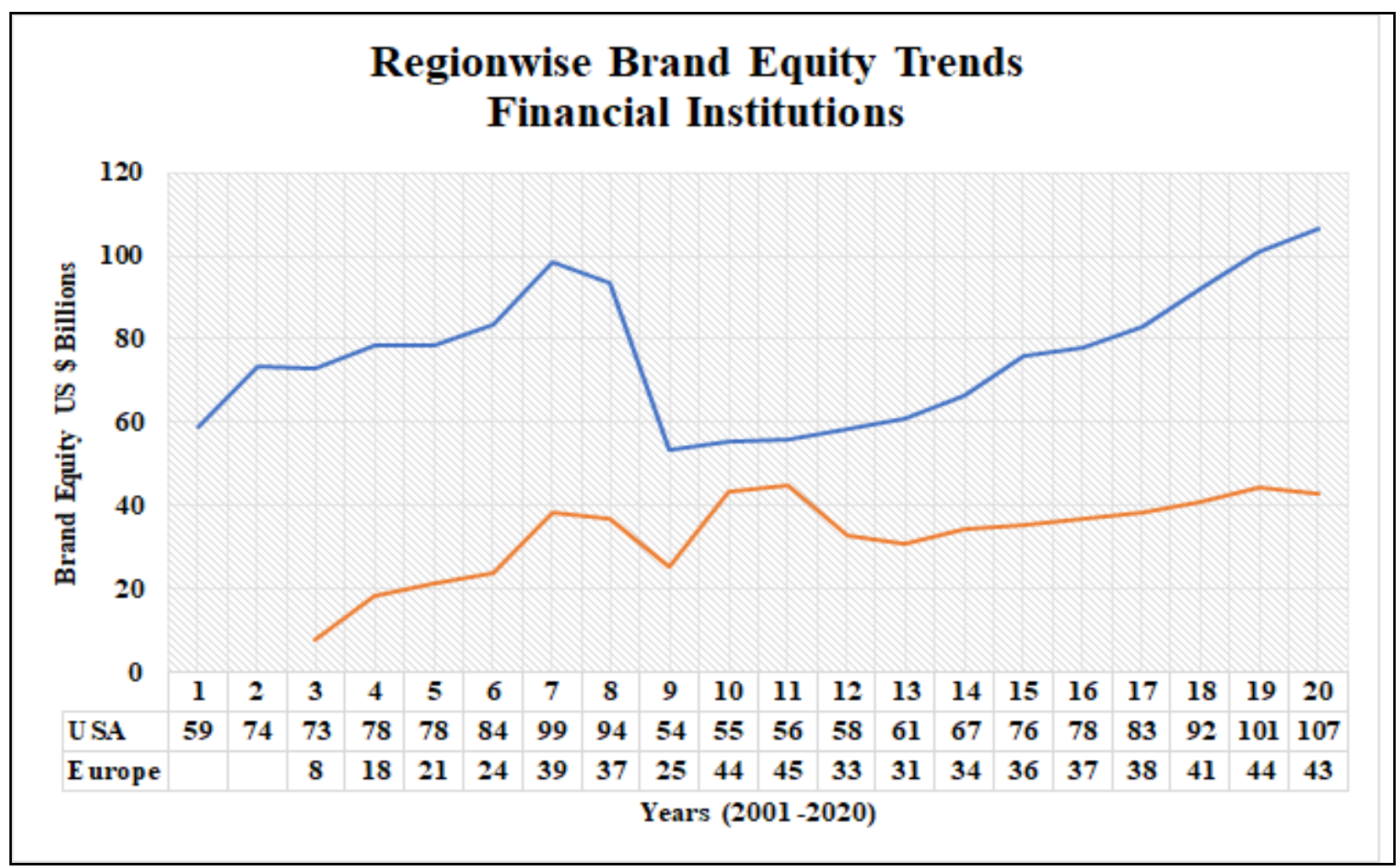

Fig. 2. Brand Equity Trends for Financial institutions (2001-2020) - Region-wise Summary Source: Authors' contribution

\subsection{Effect of the Global Crises on the Financial Institutions}

During the last two decades, the global economy has suffered from two major economic crises. Beginning in 2008, the financial crisis in the US turned into a global economic recession that affected almost all the industries and geographic regions around the globe. The Financial institution's sector was the worst affected by the aftermath of the global economic recession in 2009-10. All the global brands have gone through a rough time during 2008-09, and brand equity declined sharply, resulting in a negative growth rate in brand equity valuation of Financial Institutions. However, all financial institutions have responded proactively to this challenge. As a result, the annual aggregate brand equity of the financial institution's sector declined from $\$ 66$ billion in 2009 to $\$ 50$ billion in 2010 and regained the level of $\$ 66$ billion in 2013. The growth rate had sharply declined to $-4 \%$ in 2008 from $+4 \%$ in 2007 and regained to $+4 \%$ in 2009.

Similarly, the coronavirus turned into a pandemic by early 2020, termed as COVID19 pandemic. Coupled with a total lockdown on almost every neighbourhood on the earth, it brought the global economy to a standstill that humanity has never experienced in modern history. It affected almost every aspect of human life, especially the economic aspect. Most industries, including Financial Institutions, have shown negative growth rates during this period. The annual aggregate brand equity of the financial institution's sector declined from $\$ 118$ billion in 2019 to $\$ 114$ billion in 2020 . The growth rate had sharply declined to $-4 \%$ in 2020 from $+9 \%$ in 2019 . Figure 3 shows the global financial crisis (2008) and global pandemic (2020) on their impact on Financial Institutions' brand equity. During both global crises, all financial institutions have shown negative growth rates as compared to other brands. 


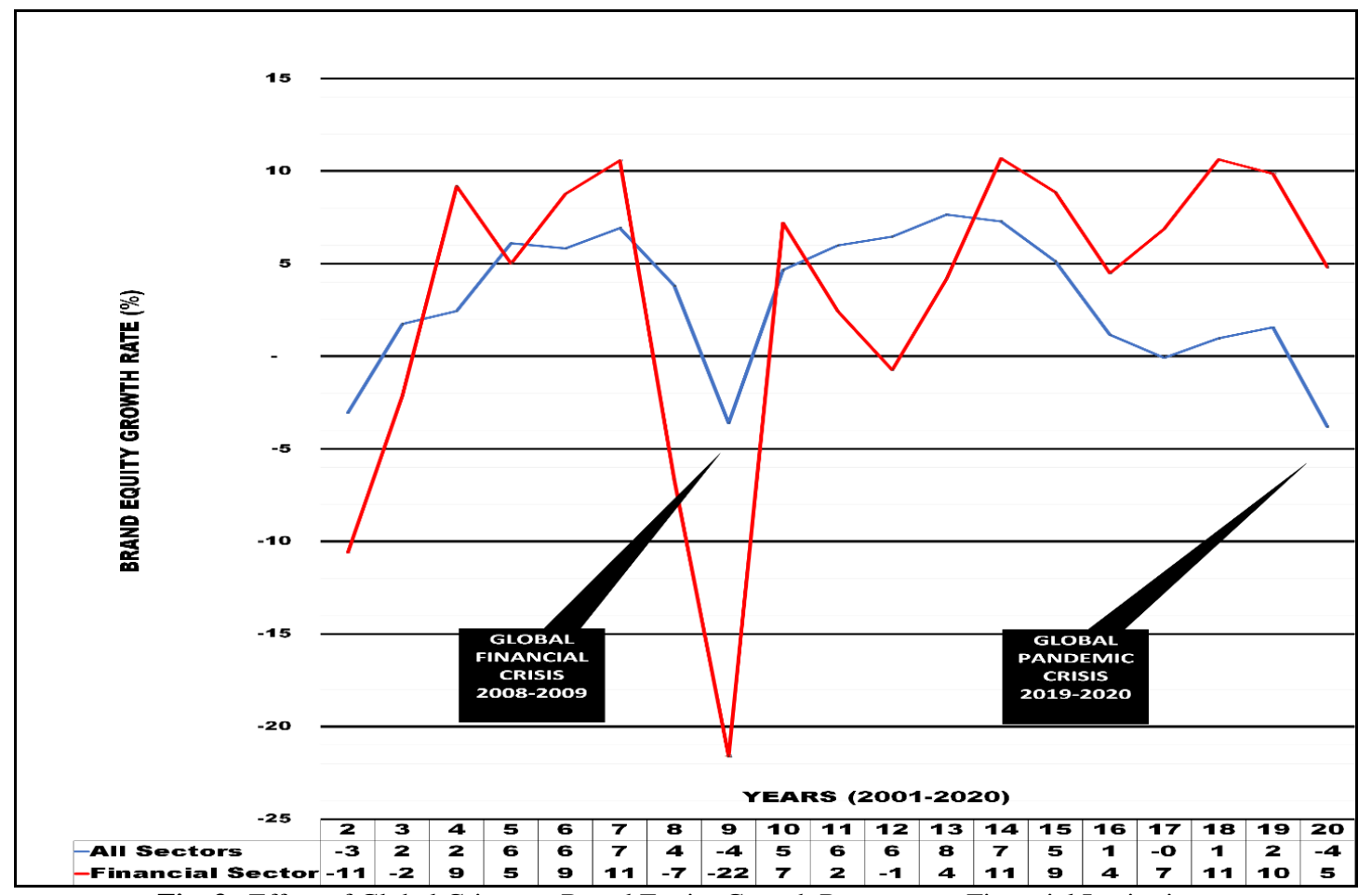

Fig. 3. Effect of Global Crises on Brand Equity Growth Rate among Financial Institutions

$$
\text { Source: Authors' contribution }
$$

The financial crisis that started in 2008 deeply affected the banking industry. Many banks were forced to go under, and governments had to bail them out. The financial stocks were crushed, and many of them were slashed. The investors who lost money were primarily foreigners. The collapse of the US financial system caused many investors to lose their money. The brand equity of financial institutions has the most significant decline. It has fallen sharply over the years. Two important observations can be made comparing the global financial crisis (2008-9) with the global pandemic crisis (2019-20). Firstly, the global pandemic crisis completely halted the world's economy for many months, but banks were not severely affected. Second, although in 2019-20, there was a decline in the growth rate of the financial sector's brand equity compared to all other sectors (See figure 6), the cumulative brand equity of the financial sector was constantly on the rise (Figure 1).

\subsection{Cluster Formation based on Brand Equity}

This research provides a cluster analysis based on 19 banks listed as Interbrand's top financial institutions (20012020). These brands are classified into three distinct clusters: Leaders, Challengers, Extinct. Table 5 shows a cluster with a brief description and banks included with their country of origin.

Figure 4 shows two clusters of financial institutions among Interbrand's top 100 global brands. On X-axis, 'Consistency' is placed, and it is measured as the number of appearances by the financial institutions on Interbrand's' Global brand list (2001-2020) with a minimum of 5 and a maximum of 20 appearances while Y-axis has brand equity growth rate (\%). The bubble size shows the brand equity of the brand (millions of USD). Figure 5 presents cumulative brand equity trends for three clusters (2001-2020). Cluster - I Leaders has high brand equity but a relatively low growth rate. Cluster - II Challengers are relatively new to the Interbrand's list but having a high growth rate. Cluster - III Extinct disappeared from Interbrand's list in 2012. 
Table 5. Clusters of Financial institutions among Interbrand's Top 100 Global Brands

\begin{tabular}{|c|c|c|c|c|}
\hline Cluster & Description & & Brand & Country \\
\hline \multirow{6}{*}{ Leaders } & \multirow{6}{*}{$\begin{array}{l}\text { Banks/ Financial institutions } \\
\text { appeared in Interbrand's Global } \\
\text { Brand List for (a) at least } 15 \\
\text { years during } 2001-2020 \text {, and (b) } \\
\text { having minimum brand equity of } \\
\text { USD } 8.0 \text { billion in } 2020 .\end{array}$} & 1 & JPMorgan & US \\
\hline & & 2 & American Express & US \\
\hline & & 3 & Goldman Sache & US \\
\hline & & 4 & Citi & US \\
\hline & & 5 & HSBC & UK \\
\hline & & 6 & Morgan Stanley & US \\
\hline \multirow{6}{*}{ Challengers } & \multirow{6}{*}{$\begin{array}{l}\text { Banks/ Financial institutions } \\
\text { appeared in Interbrand's Global } \\
\text { Brand List for (a) at least five } \\
\text { years during } 2001-2020 \text {, and (b) } \\
\text { having minimum brand equity of } \\
\text { USD } 7.0 \text { billion in } 2020 .\end{array}$} & 1 & Allianz & Germany \\
\hline & & 2 & Visa & US \\
\hline & & 3 & AXA & France \\
\hline & & 4 & MasterCard & US \\
\hline & & 5 & PayPal & US \\
\hline & & 6 & Santander & Spain \\
\hline \multirow{7}{*}{ Extinct } & \multirow{7}{*}{$\begin{array}{c}\text { Banks/ Financial institutions } \\
\text { appeared in Interbrand's Global } \\
\text { Brand List at least once during } \\
\text { 2001-2020 but not listed for the } \\
\text { last eight years. }\end{array}$} & 1 & Merrill & US \\
\hline & & 2 & UBS & Switzerland \\
\hline & & 3 & ING & Netherland \\
\hline & & 4 & Credit Suisse & Switzerland \\
\hline & & 5 & AIG & US \\
\hline & & 6 & Barclays & UK \\
\hline & & 7 & Zurich & Switzerland \\
\hline
\end{tabular}

Source: Authors' contribution

The first cluster, named 'Leaders,' was based on financial institutions having at least fifteen appearances in 20 years for the Interbrand's top 100 global brand ranking and having at least brand equity of \$8 billion in 2020 . Financial institutions included in this cluster are Goldman Sache (USA), Citi (USA), American Express (USA), JPMorgan (USA), Morgan Stanley (USA), and HSBC (UK). Figure 6 shows trend analysis for brand equity for six banks listed in this cluster (2001-2020). It shows that all banks have losses during the global financial crisis (2008-2009) and some minor losses in the global pandemic crisis (2019-2020), especially American Express and Citi banks have huge losses, but JP Morgan is continuously growing during that period. In this cluster, the average growth rate in brand equity for 20 years is $-1.8 \%$. 


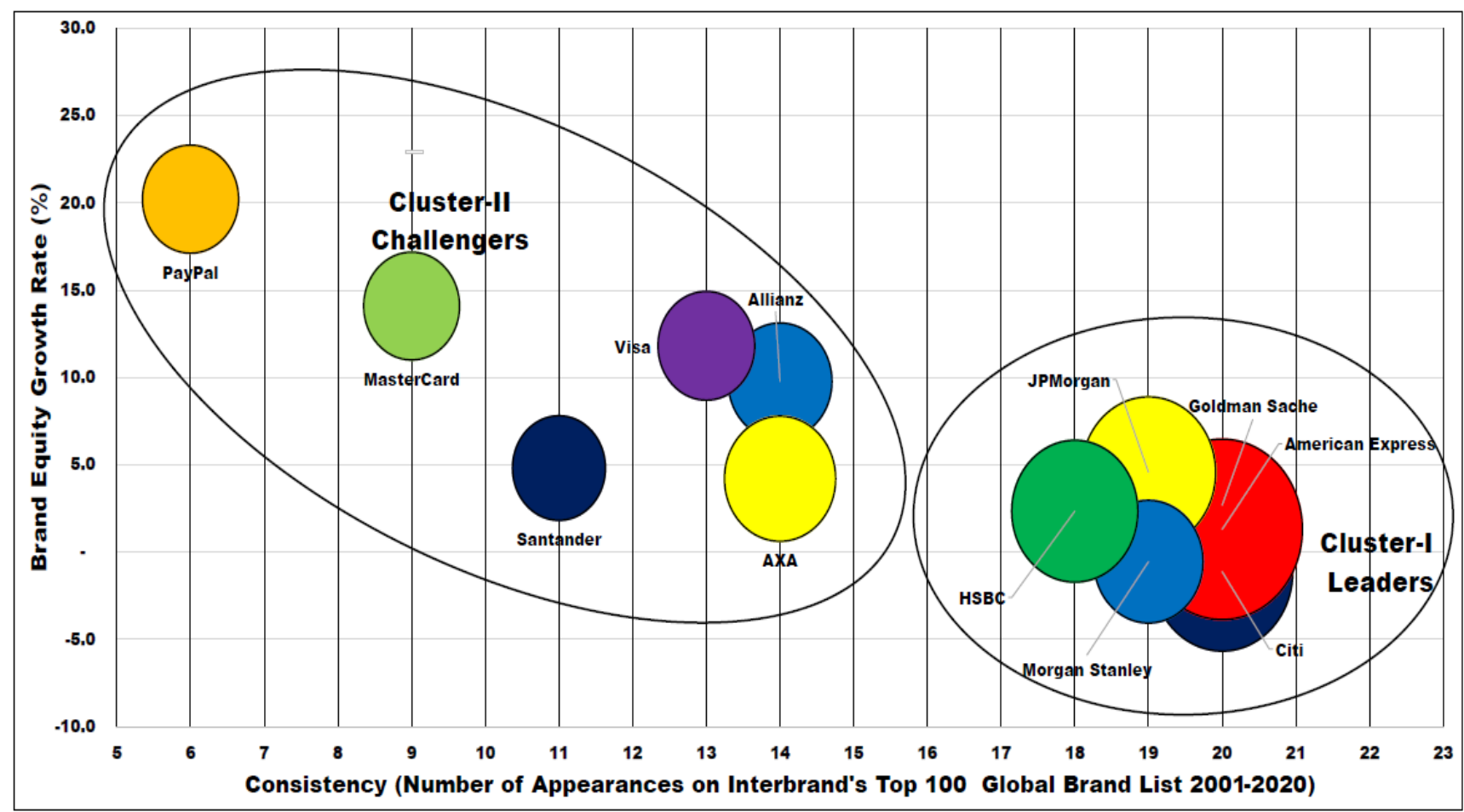

Fig. 4. Clusters of Financial institutions among Interbrand's Top 100 Global Brands Source: Authors' contribution

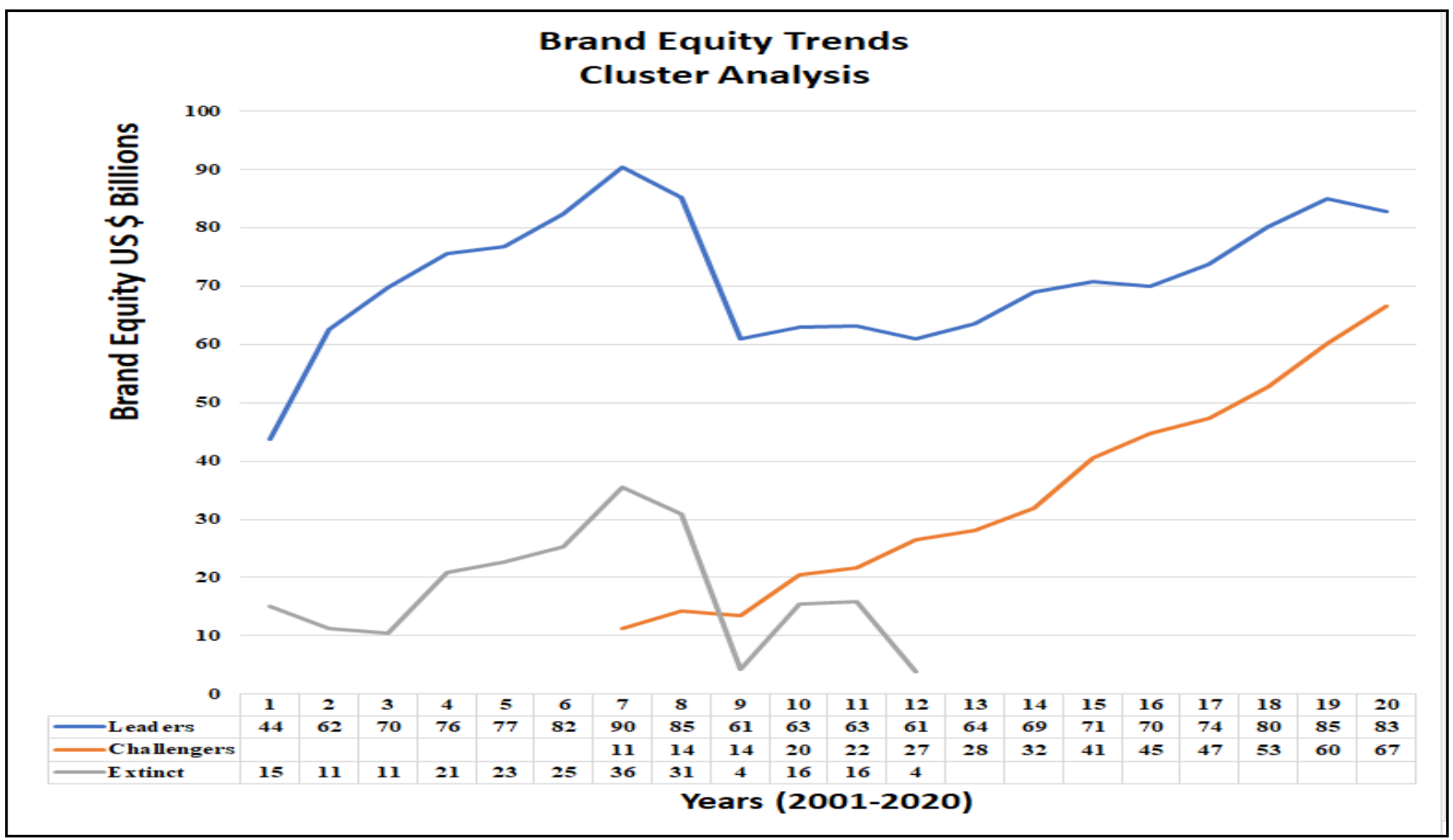

Fig. 5. Brand Equity Trends for Financial institutions (2001-2020) - Region-wise Summary Source: Authors' contribution 


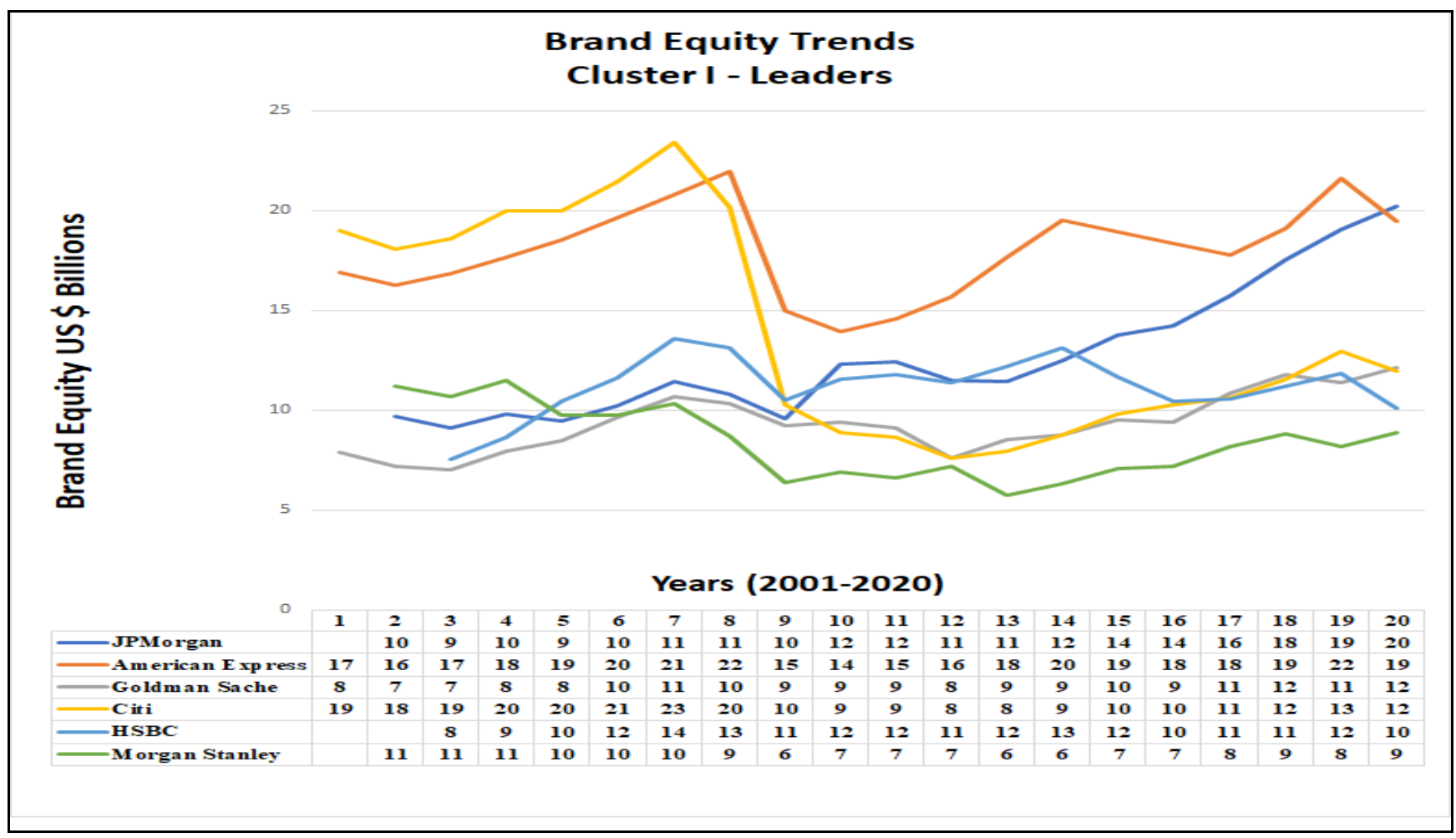

Fig. 6. Brand Equity Trends for Financial institutions (2001-2020) - Cluster 1 Leaders Source: Authors' contribution

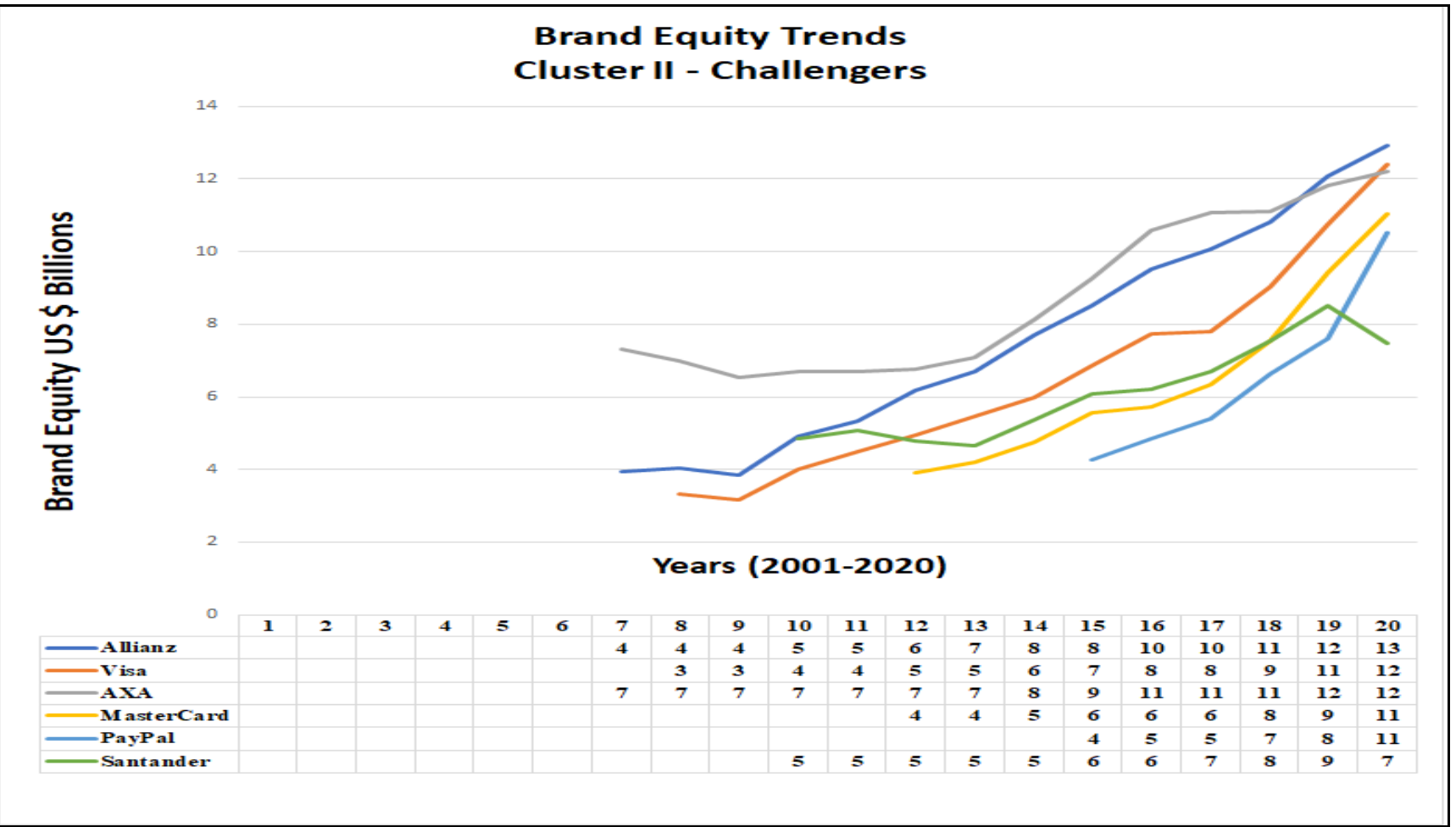

Fig. 7. Brand Equity Trends for Financial institutions (2001-2020) - Cluster II Challengers

Source: Authors' contribution 


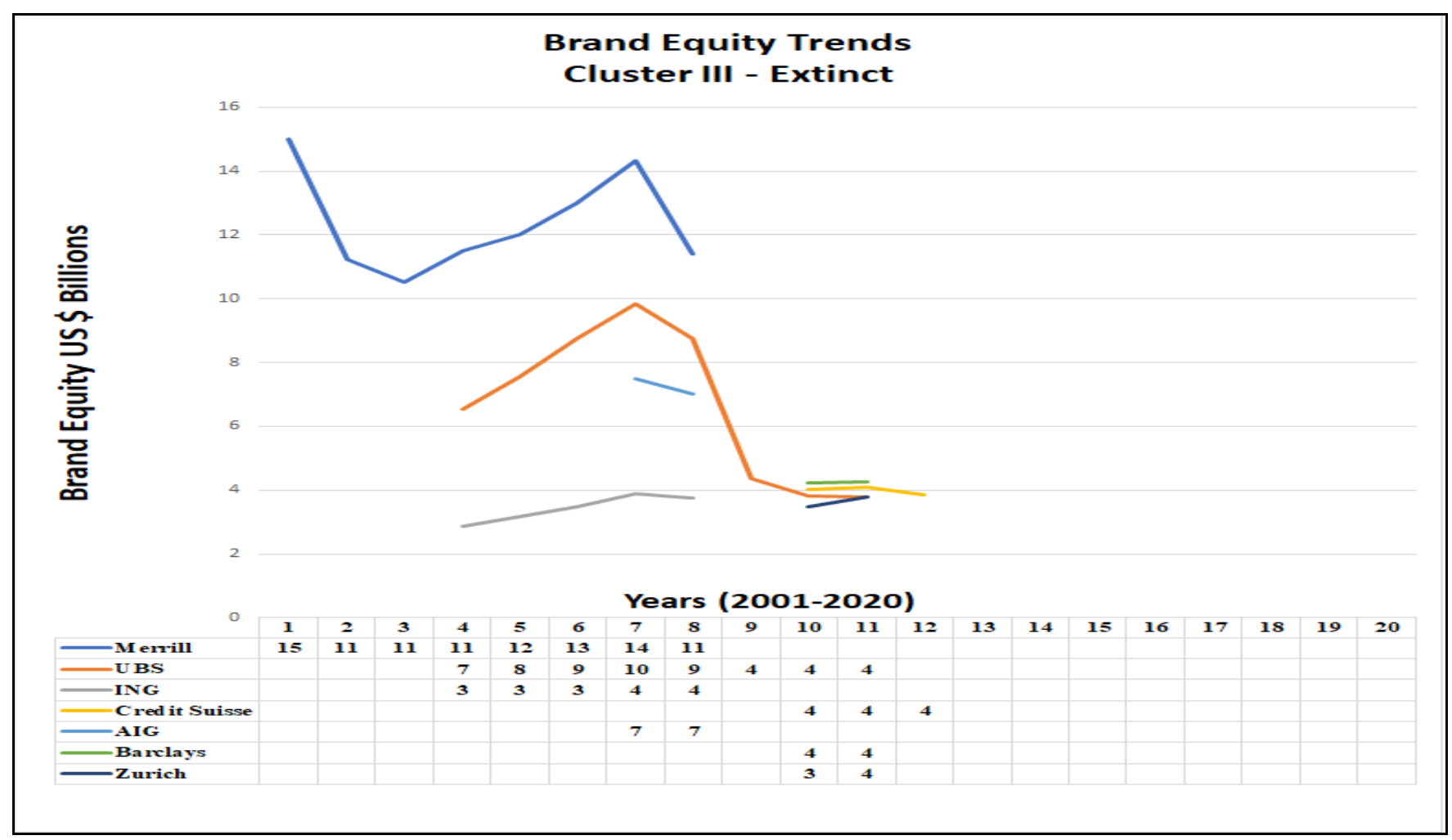

Fig. 8. Brand Equity Trends for Financial institutions (2021-2020) - Cluster III Extinct

Source: Authors' contribution

The second cluster was named 'Challengers,' having an inclusion criterion for minimum brand equity of $\$ 7$ billion in 2020 and at least five appearances in the Interbrand's top 100 global brand ranking. The reason for naming them as 'Challenger' is their growth in brand equity, reflecting aggressive branding strategies for the last couple of years. Brands included in this cluster are Allianz (Germany), AXA (France), Visa (US), Santander (Spain), MasterCard (US), and PayPal (US). Figure 7 shows brand equity trend analysis for six banks listed in this cluster (2001-2020). All banks in this cluster appeared late in this list and have shown a high growth rate. In this cluster, the average growth rate in brand equity for 20 years is $10.8 \%$.

The third cluster was named 'Extinct,' which was based on financial institutions that appeared in Interbrand's best 100 global brand List on an irregular basis. Brands included in this cluster are Merrill (US), UBS (Switzerland), ING (Netherland), Credit Suisse (Switzerland), AIG (US), Barclays (UK), and Zurich (Switzerland). Figure 8 shows brand equity trend analysis for seven banks listed in this cluster (2001-2020). No bank appeared on this list after 2012. The global financial crisis (2008-2009) is the primary reason for their disappearance from Interbrand's Top 100 Global Brand list.

\section{Conclusions}

Brand Equity is a crucial indicator that helps in assessing an organization's performance. It is also used to evaluate the customer preference of an individual brand. Establishing a solid brand image is the first step to gain a competitive advantage. The image of a financial institution is at stake when the country's economy goes through a significant change. This study shows that the brand equity of top banks has significantly varied during the 2001- 


\section{ENTREPRENEURSHIP AND SUSTAINABILITY ISSUES}

ISSN 2345-0282 (online) http://jssidoi.org/jesi/ 2021 Volume 9 Number 1 (September) http://doi.org/10.9770/jesi.2021.9.1(25)

20 periods due to financial and pandemic crises and recessions. Our study analyzed the top 100 global financial brands in 2001. The global economic recession of 2008-09 affected the financial brands of different sectors more than others.

Contrary to this phenomenon, the pandemic crisis has not severely affected the banking sector. Nevertheless, these findings have implications for practitioners and academicians to understand better the underlying patterns and changes in top global financial institutions' brand equity and devise the appropriate strategies. In addition, the findings invite future research on probing the reasons behind the drastic changes in the brand equity of various global financial institutions in the last two decades.

\section{Need for Future Research}

This trend analysis provides a baseline for further research. The agenda for further research on financial institutions and their brand equity can be grouped into three novel ideas. Firstly, it shows consistently higher brand equity growth by Cluster - II Challengers, which has a cumulative growth rate of brand equity is $10.8 \%$ for the last 20 years. Looking at the trend for this cluster million-dollar question needs to be answered 'what strategies kept them consistently growing for many years.' Secondly, more financial data might be needed to study the Cluster-I Leaders of financial institutions proposed in this paper. Thirdly, many financial institutions have shown significant turnarounds in their brand equity figures. Knowing these turnaround strategies would be beneficial for academicians and as well as for marketing professionals. All these questions require in-depth research and analysis from a brand equity point of view.

\section{Limitations}

This study has certain limitations. Firstly, this study used secondary data from Interbrand's 100 Best Global Brands ranking from 2001 to 2020. Interbrand has its particular criteria to include the brands in the global ranking and a specific valuation method for brand equity, as discussed earlier. Therefore, it may not consider some brands that do not fulfill the criteria. Secondly, the scope of this study is limited to exploring and presenting the trends using descriptive techniques and not finding the reasons behind such patterns.

\section{References}

Bartlett, W., \& Prica, I. (2011). The variable impact of the global economic crisis in South East Europe. Economic Annals, 56(191), pp 734. https://doi.org/10.2298/EKA1191007B

Cetorelli, N., \& Goldberg, L. S. (2011). Global banks and international shock transmission: Evidence from the crisis. IMF Economic review, 59(1), pp 41-76. https://EconPapers.repec.org/RePEc:pal:imfecr:v:59:y:2011:i:1:p:41-76

Chu, S., \& Keh, H. T. (2006). Brand value creation: Analysis of the Interbrand-Business Week brand value rankings. Marketing Letters, 17(4), pp 323-331. https://doi.org/10.1007/s11002-006-9407-6

Coleman, N., \& Feler, L. (2015). Bank ownership, lending, and local economic performance during the 2008-2009 financial crisis. Journal of Monetary Economics, 71, pp 50-66. https://doi.org/10.1016/j.jmoneco.2014.11.001

Cull, R., \& Peria, M. S. M. (2013). Bank ownership and lending patterns during the 2008-2009 financial crisis: Evidence from Latin America and Eastern Europe. Journal of Banking \& Finance, 37(12), pp 4861-4878. https://doi.org/10.1016/j.jbankfin.2013.08.017

Demirgüç-Kunt, A., Pedraza, A., \& Ruiz Ortega, C. (2020). Banking sector performance during the covid-19 crisis. Demirguc-Kunt A, Pedraza A, Ruiz-Ortega C. Banking Sector Performance during the COVID-19 Crisis. World Bank Policy Research Working Paper, 9363. 


\section{ENTREPRENEURSHIP AND SUSTAINABILITY ISSUES}

ISSN 2345-0282 (online) http://jssidoi.org/jesi/ 2021 Volume 9 Number 1 (September) http://doi.org/10.9770/jesi.2021.9.1(25)

Elnahass, M., Trinh, V. Q., \& Li, T. (2021). Global banking stability in the shadow of Covid-19 outbreak. Journal of International Financial Markets, Institutions and Money, 72, 101322. https://doi.org/10.1016/j.intfin.2021.101322

Habibi, N. (2009). The impact of the global economic crisis on Arab countries: a year-end assessment. Middle East Brief, 40(10).

Haselmann, R., \& Tröger, T. (2021). When and how to unwind COVID-support measures to the banking system? (No. 83). SAFE White Paper. https://doi.org/10.2861/53178

Interbrand best global brands (2021) https://interbrand.com/best-brands/

Interbrand methodology (2021) https://www.interbrand.com/thinking/best-global-brands-2020-methodology/

Jia, Y., \& Zhang, W. (2013). Brand equity valuation: an optimized Interbrand model, which is based on the consumer perspective. In international academic workshop on social science (IAW-SC-13) (pp. 325-330). Atlantis Press.

Keller, K. L. (1993). Conceptualizing, measuring, and managing customer-based brand equity. Journal of Marketing, 57(1), pp 1-22.

Manu, C., Sreejesh, S., \& Paul, J. (2021). Tell us your concern, and we shall together address! Role of service booking channels and brand equity on post-failure outcomes. International Journal of Hospitality Management, Volume: 96 Article Number: 102982 http://doi.org/10.1016/j.ijhm.2021.102982

Melović, B., Vukčević, M., \& Dabić, M. (2021). The Midas touch of branding: banks' brand value, intellectual capital, and the optimization of the Interbrand methodology. Journal of Intellectual Capital. https://doi.org/10.1108/JIC-08-2020-0272

Rambocas, M., \& Arjoon, S. (2020). Brand equity in Caribbean financial services: the moderating role of service providers. International Journal of Bank Marketing, 38(3), pp. 642-670 http://doi.org/10.1108/IJBM-05-2019-0167

Rifi, A., \& Mostafa, R.B. (2021). Brand credibility and customer-based brand equity: a service recovery perspective. Journal of Financial Services Marketing http://doi.org/10.1057/s41264-021-00106-Z Early Access: JUL 2021

Siddiqui, K. A., \& Sibghatullah, A. (2014). A Study of Fastest Growing Countries Among Top 100 Brands. International Journal of Economics, Commerce and Management, 2(11), pp. 1-9

Siddiqui, K. A., (2011). Brand Equity Trends among Top 100 Global Brands: Region-wise Analysis. In $11^{\text {th }}$ South Asian Management Forum (SAMF), Association of Management Development Institutions in South Asia (AMDISA).

Siddiqui, K. A., Bajwa, I. A., \& Elahi, M. A. (2018). Global Recession \& Global Financial Institutions: Evidence from Top 100 Global Brands (2001-2015). European Journal of Social Sciences Studies, 2(9) pp. 207-220 http://dx.doi.org/10.46827/ejsss.v0i0.291

Simon, C. J., \& Sullivan, M. W. (1993). The measurement and determinants of brand equity: A financial approach. Marketing Science, 12(1), pp 28-52.

Teixeira, J. C., Silva, F. J., Costa, F. A., Martins, D. M., \& Batista, M. D. G. (2020). Banks' profitability, institutions, and regulation in the context of the financial crisis. International Journal of Finance \& Economics, 25(2), pp 297-320. https://doi.org/10.1002/ijfe.1753

Vasileva, S. (2016). Brand Evaluation: A Review of Interbrand and Millward Brown Models. In The Priority Directions of National Economy Development: International Scientific Conference.

Dr. Ishtiaq BAJWA is an Assistant Professor of Finance at College of Business Administration, Imam Abdulrahman Bin Faisal University, Saudi Arabia. Research interests: entrepreneurial finance, venture capital, and fin-tech.

ORCID ID: 0000-0001-5296-0028

Dr. Kamran SIDDIQUI is an Associate Professor of Marketing and Entrepreneurship at the College of Business Administration, Imam Abdulrahman Bin Faisal University, Saudi Arabia. Research interests: entrepreneurship, business incubators, and accelerators, entrepreneurial marketing, venture capital.

ORCID ID: 0000-0002-5724-0991

Dr. Tarig ELTAYEB is an Assistant Professor of Management at College of Business Administration, Imam Abdulrahman Bin Faisal University, Saudi Arabia. Research interests: Management, Supply Chain Management, Operations Management.

ORCID ID: 0000-0002-7125-2171

Dr. Chaudhry K. MAHMOOD is a faculty member at College of Business Administration, Imam Abdulrahman Bin Faisal University, Saudi Arabia. Research interests: Marketing, Branding.

ORCID ID: 000-0002-5716-1011 
ENTREPRENEURSHIP AND SUSTAINABILITY ISSUES

ISSN 2345-0282 (online) http://jssidoi.org/jesi/

2021 Volume 9 Number 1 (September)

http://doi.org/10.9770/jesi.2021.9.1(25)

Make your research more visible, join the Twitter account of ENTREPRENEURSHIP AND SUSTAINABILITY ISSUES: @Entrepr69728810

Copyright (C) 2021 by author(s) and VsI Entrepreneurship and Sustainability Center

This work is licensed under the Creative Commons Attribution International License (CC BY).

http://creativecommons.org/licenses/by/4.0/

c) (7) Open Access 